\title{
PPARD Gene
}

National Cancer Institute

\section{Source}

National Cancer Institute. PPARD Gene. NCI Thesaurus. Code C96460.

This gene is involved in signaling and transcriptional regulation. 